\title{
A dichotomous species of Codium (Bryopsidales, Chlorophyta) is colonizing northern Chile
}

\author{
Una especie dicotómica de Codium (Bryopsidales, Chlorophyta) \\ está colonizando el norte de Chile
}

ALEJANDRA GONZÁLEZ \& BERNABÉ SANTELICES

Departamento de Ecología, Facultad de Ciencias Biológicas, Pontificia Universidad Católica de Chile, Casilla 114-D, Santiago, Chile; e-mail: bsanteli@bio.puc.cl

\begin{abstract}
In late 2001 and early 2002, a dichotomous species of Codium appeared colonizing the low intertidal and

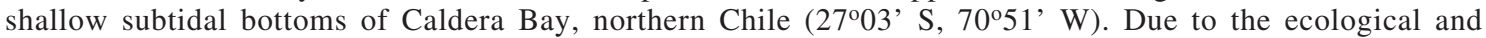
economic impact the species is having in Caldera Bay and its potential spread along the Chilean coastline, we studied the taxonomic identity of the species and examined its relationships with other dichotomous species of Codium reported for temperate Pacific South America. Morphological analyses suggest that the seaweeds from Caldera Bay belong to Codium fragile (Suringar) Hariot. Not only is there strong agreement in internal and external morphological characters, but among all the species reported for Peru and Chile, this is the only one exhibiting utricles with rounded, apiculate tip terminating in a mucron. This species has a broad geographic distribution in temperate waters. In Chile it was known only from the coasts of Valdivia to the

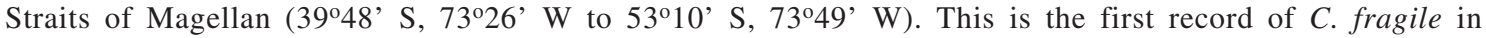
northern Chile, and this study discusses several alternative hypotheses for the presence of the species into this area. The morphological characteristics of the material collected in Caldera partially agree with diagnostic characters known for $C$. fragile subspecies tasmanicum and $C$. fragile subspecies tomentosoides. However, the rapid population spread of the species in northern Chile, and recent molecular analysis support the identification of this form as the invasive $C$. fragile subspecies tomentosoides.
\end{abstract}

Key words: Codium, introduced species, Chlorophyta, seaweed, northern Chile.

\section{RESUMEN}

A fines de 2001 y principio de 2002 apareció en el norte de Chile una especie del género Codium, de morfología dicotómica, colonizando los niveles intermareales y submareales de la Bahía de Caldera $\left(27^{\circ} 03^{\prime}\right.$ S, $70^{\circ} 51^{\prime}$ O). Debido al impacto ecológico y económico que ha provocado esta especie en la Bahía de Caldera y a su dispersión potencial a lo largo de la costa de Chile, estudiamos la identidad taxonómica de la especie, examinando su relación con las especies de Codium de hábito erecto descritas para la costa temperada del Pacífico Sudamericano. El análisis morfológico sugiere que el alga encontrada en la Bahía de Caldera corresponde a la especie Codium fragile (Suringar) Hariot. Tanto los caracteres morfológicos internos como externos del alga son concordantes con la descripción de la especie, incluyendo utrículos de ápices redondeados apiculados terminados en un mucron puntiagudo. Esta especie posee una amplia distribución geográfica en aguas temperadas. En Chile, es conocida solo para las costas entre Valdivia y Magallanes $\left(39^{\circ} 48^{\prime} \mathrm{S}, 7^{\circ} 26^{\prime} \mathrm{O}\right.$ a $\left.53^{\circ} 10^{\prime} \mathrm{S}, 7^{\circ} 49^{\prime} \mathrm{O}\right)$. Este es el primer registro de $C$. fragile en el norte de Chile y además este estudio discute diversas hipótesis alternativas de introducción de la especie en el área. Las características morfológicas de los materiales colectados en Caldera concuerdan parcialmente con los caracteres diagnósticos conocidos para $C$. fragile subespecies tasmanicum y $C$. fragile subespecies tomentosoides. Sin embargo, la expansión poblacional rápida que la especie está mostrando en el norte de Chile junto con análisis moleculares recientes apoyan la identificación de estas poblaciones como pertenecientes a la subespecie tomentosoides.

Palabras clave: Codium, especies introducidas, Chlorophyta, algas, norte de Chile. 


\section{INTRODUCTION}

Codium Stackhouse (Bryopsidales, Codiaceae) is one of the most common and widespread seaweed genera in the world (Silva 1951). There are about 100 described species, growing on rocky or sandy habitats in tropical and temperate waters (Goff et al. 1992, Silva 1992). External morphology includes individuals that have either a crustose, cushion-like form that covers the substratum ("the prostrate species") or that attach to the substratum at a single point, with the rest of the plant being erect and with cylindrical dichotomously branched axes ("the dichotomous species"). Both morphological types are composed of a tightly woven mass of coenocytic medullary filaments surrounded by a cortex of utricles. The utricles, which are the swollen cortical tips of the filaments, typically have colourless spine-like, rounded or pointed cell wall projections and cell thickenings, frequently used as taxonomic characters (Silva 1955, Burrows 1991).

A total of 14 species of Codium have been described for temperate Pacific South America (see Ramirez \& Santelices 1991 for listing). Of these, eight species are dichotomous and six are prostrate. Not a single dichotomous species has been reported from northern or central Chile (Arica to Concepción; $18^{\circ} 29^{\prime} \mathrm{S}, 70^{\circ} 19^{\prime}$ 'W to $\left.36^{\circ} 47^{\prime} \mathrm{S}, 73^{\circ} 14^{\prime} \mathrm{W}\right)$. The dichotomous $C$. contractum, $C$. tomentosum and $C$. fragile have been described for southern Chile (Concepción to the Straits of Magellan), while $C$. fernandezianum, C. pocokiae and C. unilaterale have been registered for the Chilean oceanic islands only (Isla de Pascua, Juan Fernández y Desventuradas). On the other hand, $C$. peruvianum and $C$. foveolatum have been ascribed to the Peruvian coast only (Paita, Piura and Lima, and Piura respectively).

In late 2001 and early 2002, a dichotomous species of Codium appeared colonizing the low intertidal and shallow subtidal bottoms of Caldera Bay in northern Chile $\left(27^{\circ} 03^{\prime}\right.$ S, $70^{\circ} 51^{\prime}$ W, E. Martínez personal communication). By the end of August of 2003 the species had already spread to Obispito, $45 \mathrm{~km}$ to the north of Caldera Bay, and to Huasco, $176 \mathrm{~km}$ to the south of Caldera Bay (Neill et al. 2003) ${ }^{1}$. Many of these bays in northern Chile are habitat to a

\footnotetext{
${ }^{1}$ NEILL P, O ALCALDE \& J CORREA (2003) Presencia de la especie invasora Codium fragile (Chlorophyta) en el norte de Chile: efectos potenciales sobre cultivos de Gracilaria chilensis (Rhodophyta). Abstracts of the XLVI Reunión Anual de la Sociedad de Biología de Chile, XVI Reunión Anual de la Sociedad de Ecología de Chile, Puyehue, Chile: R-56.
}

highly endemic native fauna and flora (Santelices 1980, Meneses \& Santelices 2000, Santelices \& Meneses 2000), and in recent years, they have become cultivation grounds for economically important seaweeds (e.g., Gracilaria) and shellfish (e.g., Pacific oysters).

Due to the ecological and economic impact the species may have in Caldera Bay, and in the rest of the northern Chilean coastline, here we report the taxonomic identity of the species, and discuss its potential means of introduction in this area.

\section{MATERIAL AND METHODS}

The algal samples were collected by E. Martínez by SCUBA and skin diving at different depths $(2-10 \mathrm{~m})$ in Caldera Bay $\left(27^{\circ} 03^{\prime} \mathrm{S}, 70^{\circ} 51^{\prime} \mathrm{W}\right)$ between January and April 2002. In total, 19 specimens were analyzed and have been deposited in the herbarium of the Sala de Sistemática, Pontificia Universidad Católica de Chile (SS/UC n ${ }^{\circ} \mathrm{s}$ 6911-1 to 6911-16 and 6913-1 to 6913-4). The length of erect axes and diameter and number of dichotomies were used to compare the external morphology of this species with that of other species reported for the region. Size, shape and apical structure of utricles were used as internal taxonomic characters. Utricles were stained with aniline blue and micrographs were taken using a Nikon Labophot microscope.

\section{RESULTS}

\section{Taxonomic identity at the species level}

Eleven of the 19 specimens examined exhibited gametangia, suggesting $57.9 \%$ fertility in the studied sample. All 19 specimens had similar external (Table 1, Fig. 1), and internal (Table 1, Figs. 2 and 3) characters.

Externally, the plants have several cylindrical, robust fronds, up to $40 \mathrm{~cm}$ long, which arise from a broad, spongy, basal disk (Fig. 1). Branches are blackish green, and dichotomous for up to six orders. The cylindrical or terete branches are $5 \pm 2 \mathrm{~mm}$ in diameter at the base, $4 \pm 0.5 \mathrm{~mm}$ in diameter at the middle portions and $2.4 \pm 0.3 \mathrm{~mm}$ in diameter at the tips. The utricles are cylindrical to clavate, frequently with constriction at approximately around the middle of the utricle (see arrows in Fig. 2). The utricles measure 910 $\pm 150 \mathrm{~m}$ long and $316 \pm 76 \mu \mathrm{m}$ in diameter. The wall of the utricle is $160 \pm 2.6 \mu \mathrm{m}$ thick, 


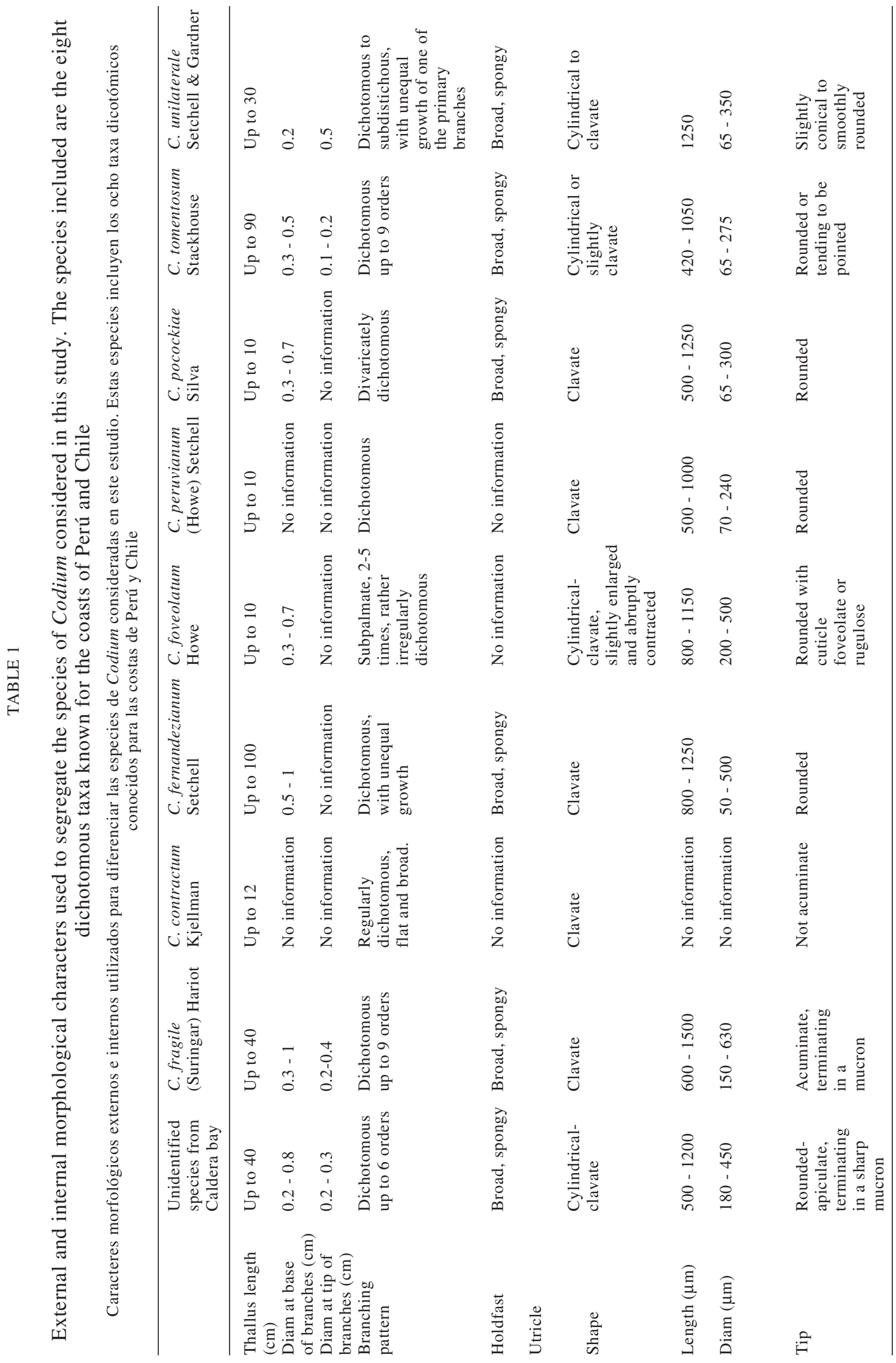




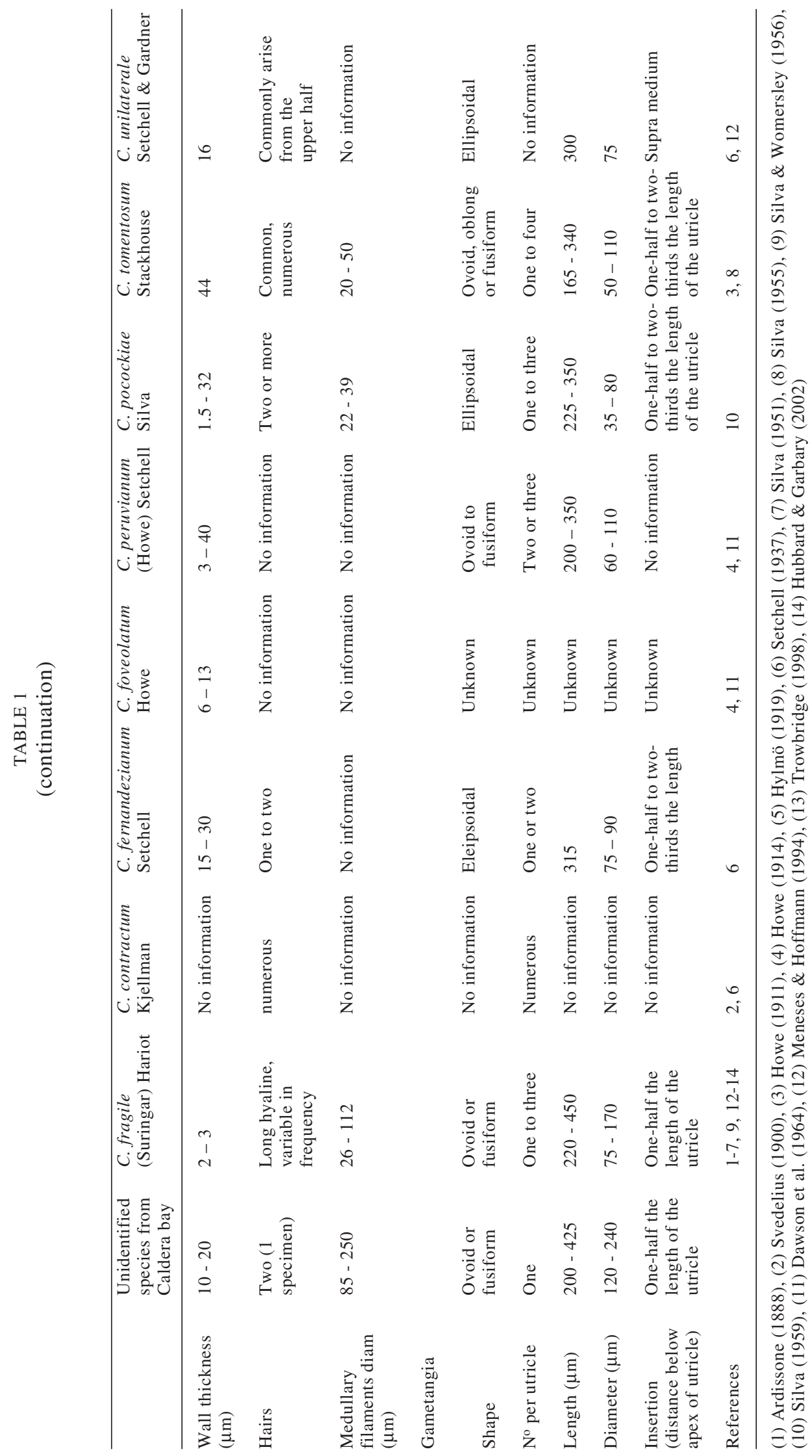




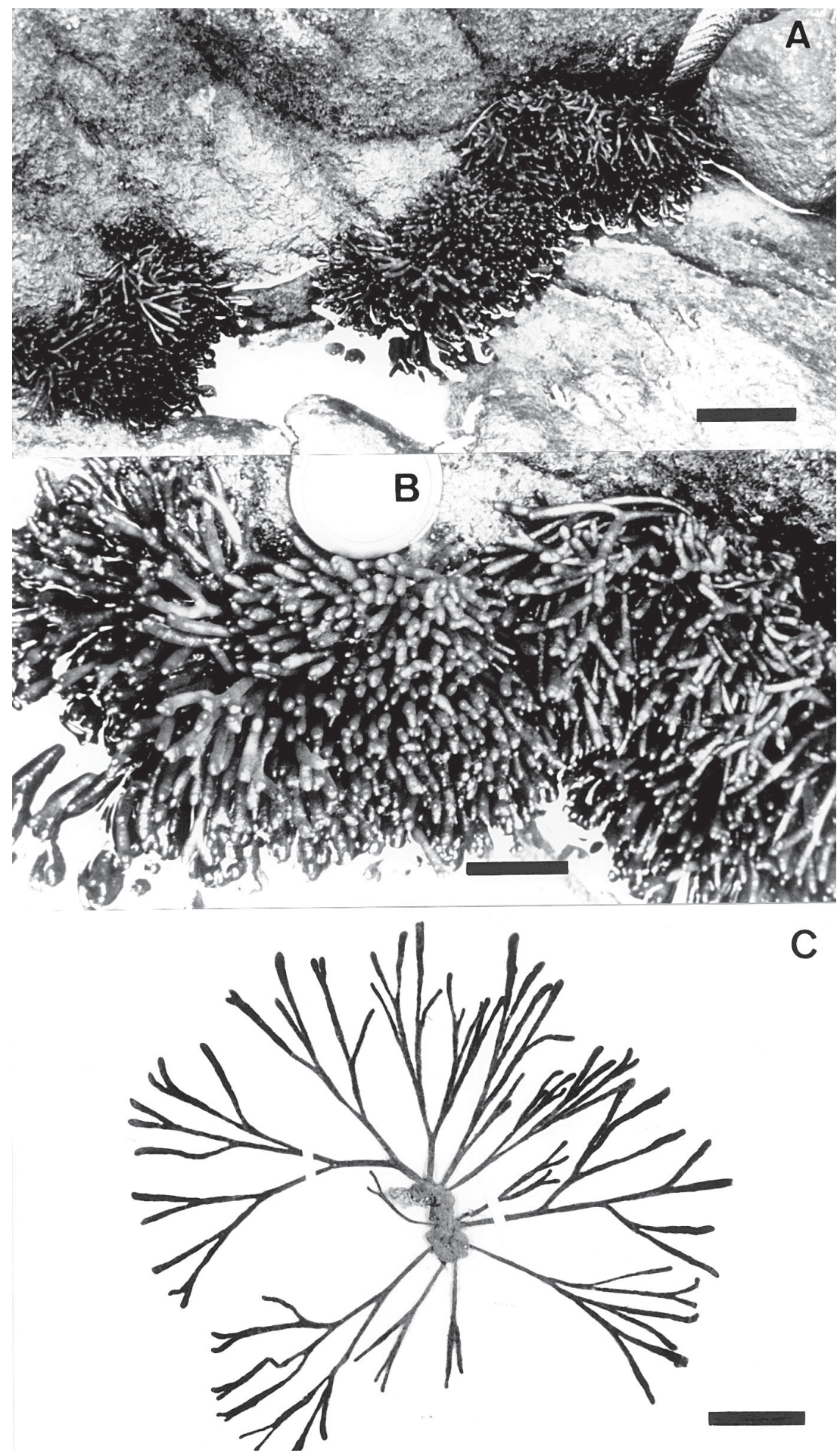

Fig. 1: Specimens of Codium fragile from Caldera Bay. (A) \& (B) exhibit the thallus external morphology of the species growing on rocky, wave sheltered habitats. Scales $=8$ and $4 \mathrm{~cm}$, respectively. (C) Elongated herbarium specimen (SSUC No 6913) exhibiting the basal disk and the dichotomously branched erect axes. Scale $=4 \mathrm{~cm}$.

Especímenes de Codium fragile recolectados en la Bahía de Caldera. (A) y (B) muestran la morfología externa del talo de la especie creciendo sobre sustrato rocoso en ambientes protegidos del oleaje. Escala $=8$ y $4 \mathrm{~cm}$, respectivamente. (C) Ejemplar de herbario (SSUC N ${ }^{\circ}$ 6913) mostrando el disco basal y los ejes erectos con ramificaciones dicotómicas. Escala $=4 \mathrm{~cm}$. 


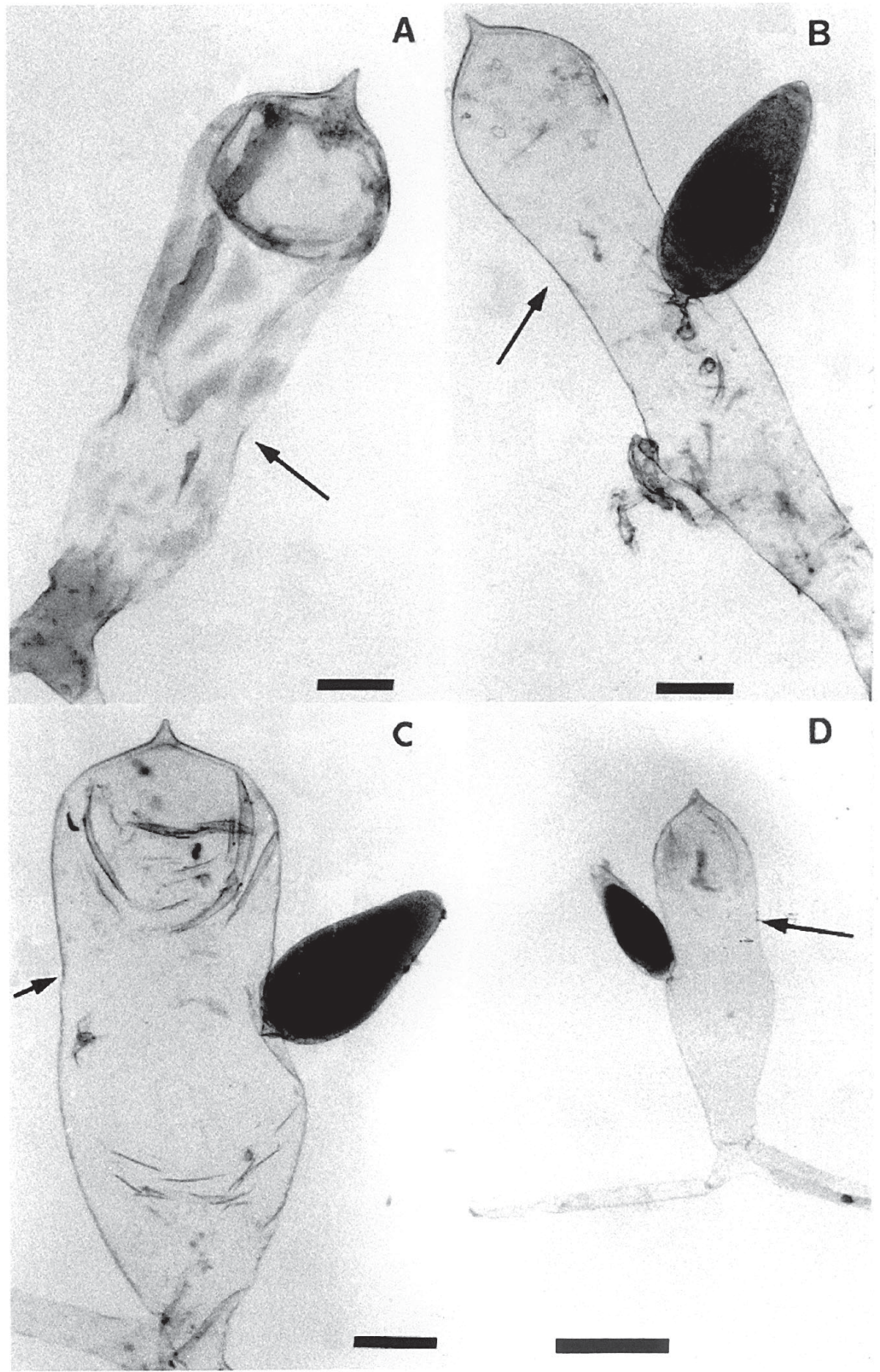

Fig. 2: Variability in the dimensions and shapes of utricles and gametangia. Arrows indicate the constriction at or slightly below the middle points of the utricles. All the utricles exhibit the pointed mucron. Scales in A, B and C are $100 \mu \mathrm{m}$. Scale in D is $200 \mu \mathrm{m}$.

Variabilidad en dimensiones y forma de utrículos y gametangios. Las flechas indican la constricción del utrículo en el punto medio o por debajo de este punto. Todos los utrículos muestran el mucron puntiagudo. La escala en A, B y C es de $100 \mu \mathrm{m}$. La escala en D es de $200 \mu \mathrm{m}$. 


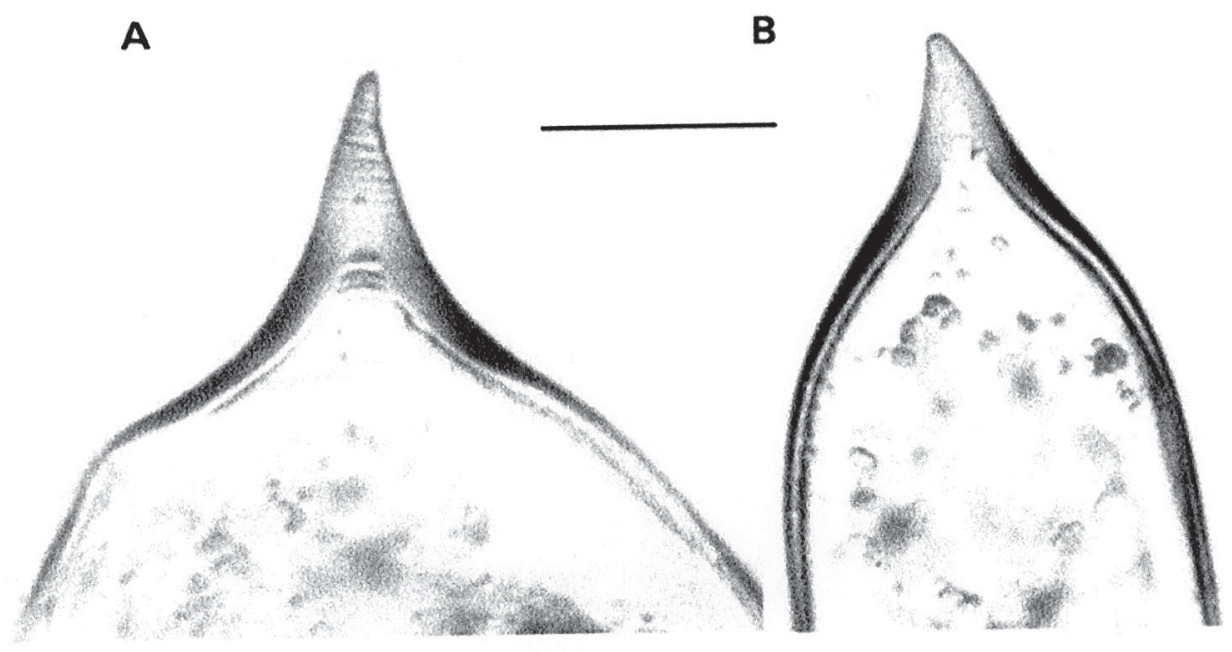

Fig. 3: Details of the mucron at the tip of the utricle in the materials from Caldera Bay (SSUC No 6913). Scale $=100 \mu \mathrm{m}$.

Detalle de extremo apical del utrículo con el mucron en los especímenes de la Bahía de Caldera (SSUC No 6913). Escala = $100 \mu \mathrm{m}$.

the apex is rounded, apiculate, terminating in a sharp mucron of $108 \pm 30 \mu \mathrm{m}$ long (Fig. 3). The medullary filaments are $191 \pm 40 \mu \mathrm{m}$ in diameter. Hairs (two per utricle) were observed on only one of the 19 specimens studied. Gametangia (Fig. 2) are ovoid or fusiform, 313 $\pm 67 \mu \mathrm{m}$ long, $160 \pm 37 \mu \mathrm{m}$ diameter, one per utricle, with each borne on a $90 \pm 40 \mu \mathrm{m}$ long protuberances or on pedicels produced near the middle part of the utricle (about $436 \pm 96 \mathrm{~mm}$ below the apex). Generally the gametangium does not extend beyond the tips of the utricles.

The spongy body of Codium serves as a host to various epiphytes and endophytes. The specimens from Caldera harbored a particularly rich epiphytic flora, including species of Ectocarpus, Ceramium, Ulva and Chaetomorpha.

A comparison of the microscopic and macroscopic characteristics of the specimens from Caldera Bay with the diagnostic characteristics of the other eight species reported for temperate Pacific South America (Table 1) suggests that the Caldera specimens belong to the species Codium fragile (Suringar) Hariot. Not only is there strong agreement in internal and external morphological characters, in addition, $C$. fragile is the only species exhibiting rounded-apiculate tips terminating in a sharp mucron, as observed in the material from Caldera.
Subspecific identity in Codium fragile and geographic distribution

Although most of the species of Codium have narrow geographic ranges and exhibit little morphological variability (Silva 1951), C. fragile has an extended distribution and a bewildering spectrum of morphological types (Goff et al. 1992). Regarded as native from Japan, the species also has been found in Korea and China. In the eastern north Pacific, the species is known from Sitka, Alaska to Puerto San Bartolomé in Baja California, Mexico. In the South Pacific it has been collected in Australia, New Zealand and southern Chile (Valdivia, Osorno and Puerto Montt). In the Indian Ocean it is known from Natal (South Africa), Kerguelen Island and Australia. In the north Atlantic it has been found in Norway, Sweden, Denmark, The Netherlands, Scotland, Ireland and Atlantic Canada. In the south Atlantic it is known from southwest Africa, Cape Province (South Africa), and southern Argentina (Tierra del Fuego and the Falkland Islands) (Silva 1951, Trowbridge 1998, Hubbard \& Garbary 2002).

Along with this widespread geographic distribution, Codium fragile exhibits much morphological variation, which has formally been recognized under the identity of seven subspecies. Gross morphological differences 
among the subspecies of $C$. fragile are not always obvious, particularly in areas where several subspecies coexists (Trowbridge 1999). However, the most reliable subspecific characters are the size and shape of the utricle, dimensions of the mucron, number of fronds per thallus and branch width. Less reliable diagnostic characters include length and thickness of the thallus and the flatness of fronds below the dichotomies (Silva 1951, 1957, Silva \& Womersley 1956, Trowbridge 1996, 1998, Hubbard \& Garbary 2002). It should be noted, however, that no experimental study has yet evaluated whether the different morphologies represent independent subspecies, or patterns of phenotypic plasticity adapting to local environments (Trowbridge 1996, Hubbard \& Garbary 2002).

Four of the seven subspecies of Codium fragile are considered non-invasive and exhibit restricted geographic distributions. Thus, $C$. fragile capense occurs on South African shores only; C. fragile fragile is found from Sitka, Alaska down to Baja California and the islands along that coast (Silva 1951). C. fragile novaezelandiae is restricted to New Zealand, southeast Australian shores and southern Argentina; while $C$. fragile tasmanicum is found on southeast Australian shores (Trowbridge 1996).

The other three subspecies of Codium fragile are considered invasive. One of them, C. fragile atlanticum, is thought to have originated in Japan and been unintentionally introduced with shellfish in southwest Ireland in about 1808 (Silva 1955, Trowbridge \& Todd 1999, Hubbard \& Garbary 2002, Trowbridge 2002). Subsequent spreading, most likely through rafting or floating, expanded its range to now include Norway, the rest of The British Isles and eastern Canada (Silva 1955, 1957, Hubbard \& Garbary 2002). Codium fragile scandinavicum, was introduced to Denmark in 1919, and thereafter spread throughout northern Europe. Now it is found in Sweden and Norway and other parts of Scandinavia as well as Vladivostok, Siberia, and Yokohama (Japan) (Silva 1957). C. fragile tomentosoides is more or less cosmopolitan throughout temperate waters. It was first detected in Holland, Europe around 1900, in Denmark in 1919, Sweden in 1933, England in 1939, Norway in 1946 and Scotland in 1953 . The alga rapidly spread throughout the Mediterranean during World War II (Silva 1955, 1957, Trowbridge 1999 and references therein). C. fragile tomentosoides next appeared on northwest Atlantic shores in 1957 and is now distributed from North
Carolina to Nova Scotia, Price Edward Island, and eastern Canada (Silva 1957, Carlton \& Scanlon 1985, Garbary et al 1997, Garbary \& Jess 2000, Hubbard \& Garbary 2002). In the mid-1970's, C. fragile tomentosoides appeared in San Francisco, California, on the Pacific coast of the United States (Coleman 1996). The first appearance of $C$. fragile tomentosoides in the Southern Hemisphere was in Auckland harbor, New Zealand in 1973 (Trowbridge 1995, 1996, 1999). In 1995 the alga was first reported in Australia at Corner Inlet, Victoria, thereafter it has spread some $160 \mathrm{~km}$ to southwest Australia (Trowbridge 1999 and references therein).

The morphological characteristics of the material collected in Caldera Bay agree well with the diagnostic characters known for $C$. fragile subspecies tasmanicum and $C$. fragile subspecies tomentosoides (Table 2). Both subspecies are similar in many external and internal characters but differ in the presence of a constriction in the middle parts of the utricles and in the shape of the tip of the utricle. The material from Caldera Bay resembles $C$. fragile tomentosoides, having a constriction at or just below the middle parts of the utricles (Fig. 2). But they also resembles $C$. fragile tasmanicum because the utricle tips end in a sharp mucron (Fig. 3). The rapid population spread the species experiencing in northern Chile add support to the identification of this form as the invasive $C$. fragile tomentosoides, a conclusion additionally supported by application of molecular techniques to the materials from northern Chile (C. Maggs personal communication to Dr. J. Correa). It should be mentioned, however, that the Caldera materials exhibit some morphological variation with $C$. fragile tomentosoides. The Caldera materials generally lack hairs on the utricles which are described as common in $C$. fragile tomentosoides. Additional populations should be studied to achieve a more comprehensive view of the taxonomic importance of this morphological variation.

\section{DISCUSSION AND CONCLUSIONS}

Among the eight dichotomous species of Codium described for Pacific temperate waters, the materials found in Caldera Bay exhibit morphological characters typical of the species Codium fragile. This finding constitutes a new record for the species along the Chilean coast. At a subspecific perspective, the morphological characters used did not allow discrimination 


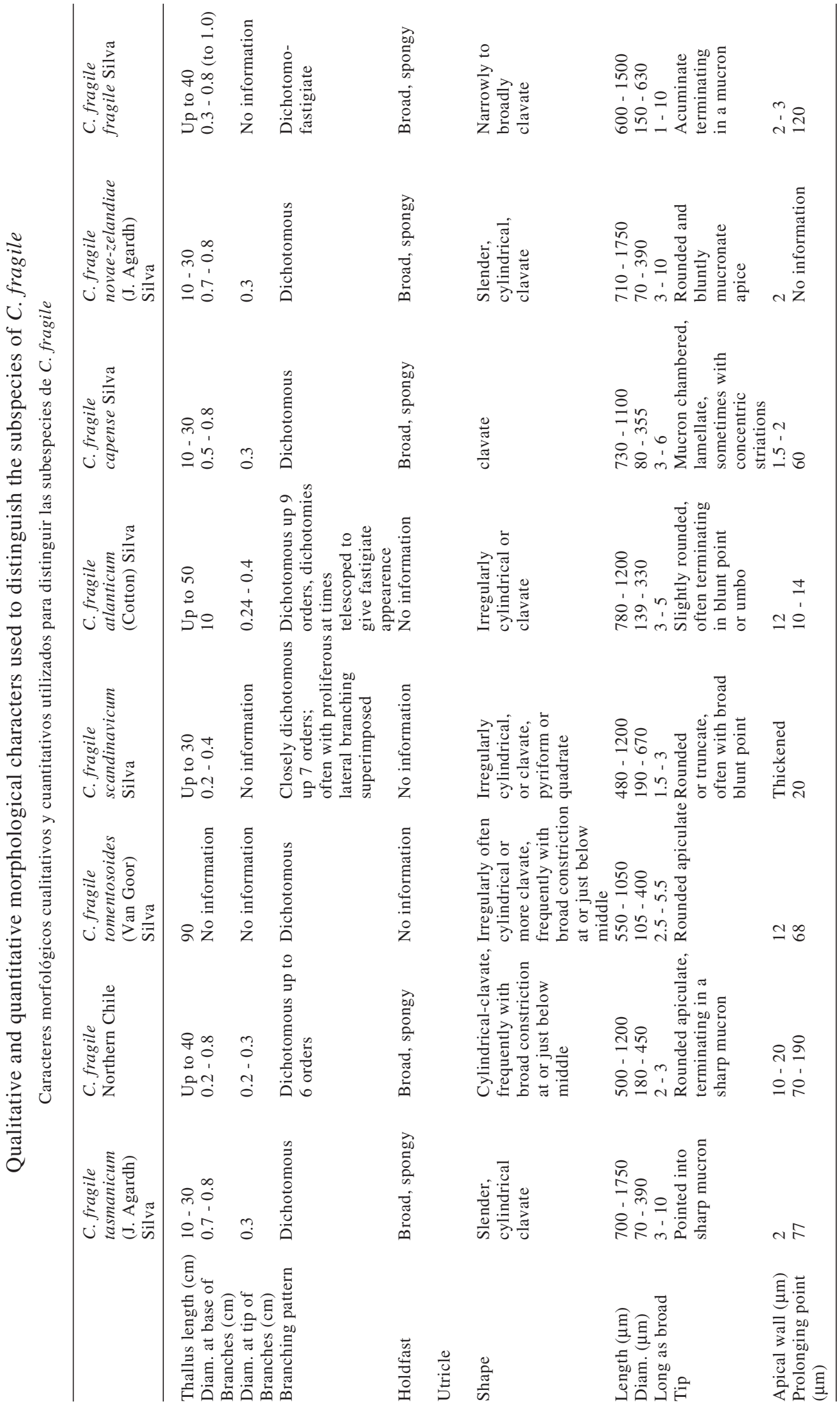




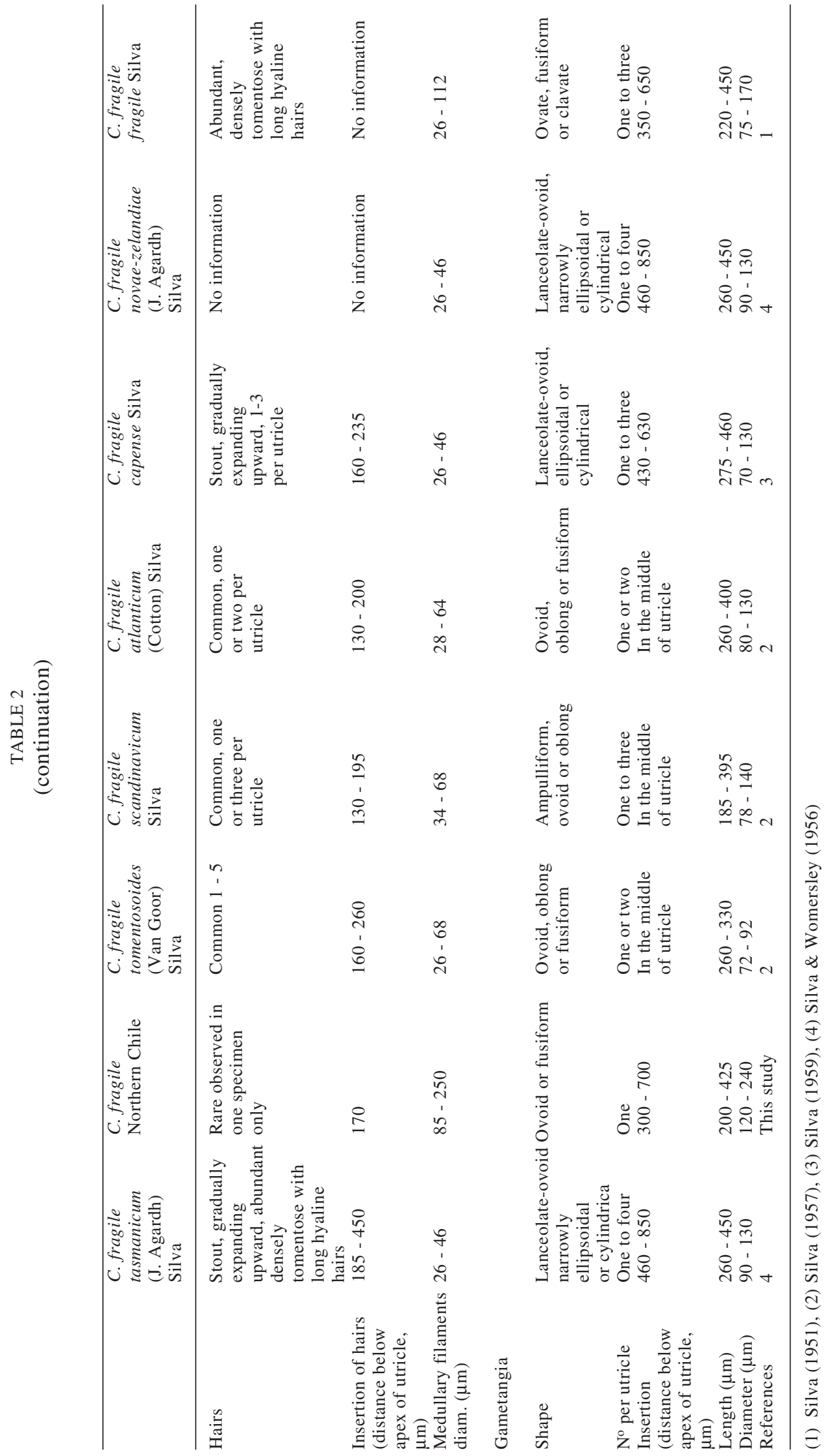


between the subspecies tomentosoides and tasmanicum. It should be noted that some recent experimental evidence (Trowbridge 1996, Hubbard \& Garbary 2002) suggests that subspecific differences in $C$. fragile could be attributed in part to environmental factors such as wave exposure, substrate stability and light availability. Future studies with a larger number of individuals and with additional techniques (e.g., molecular markers) may help to evaluate the validity of the Chilean $C$. fragile subspecies. The application of the molecular techniques (plastid microsatellites) adds support to the identification of this form as the invasive $C$. fragile tomentosoides.

One can only speculate about the mechanism by which Codium fragile might have arrived into Caldera Bay. A first possibility would be the transplantation of shellfish (e.g., Pacific oysters) or seaweed (e.g., Gracilaria) contaminated with $C$. fragile either from southern Chile or abroad (Japan). This mechanism has been used by several authors to explain the arrival of $C$. fragile tomentosoides on the shores of England and Scotland, the Mediterranean and Virginia, Maine, Massachusetts, Rhode Island and San Francisco in the United States (see review by Carlton \& Scanlon 1985, Trowbridge 1999). Alternatively, $C$. fragile may have inadvertently been introduced via ballast waters or attached to the hull of a ship or pleasure craft. The Caldera harbor and nearby ports are home to a commercial fleet that transports Chilean fruit, fishmeal and minerals along the Chilean coast and to other countries. A similar mechanism has been used to explain the introduction of $C$. fragile on New Zealand shores, because the alga first appeared at the container terminal in the port of Auckland (Trowbridge 1999 and references therein).

As it has occurred in other latitudes, the size and abundance of this recent invader of bays and sheltered habitat in northern Chile will provide a good opportunity to experimentally test several biological hypotheses related to its origin, physiological plasticity and community effects. Molecular studies similar to those done with Caulerpa taxifolia (Vahl) C. Agardh and Codium fragile (Goff et al. 1992, Wiedenmann et al. 2001) should help to trace its geographic origin and genetic similarity at the intraspecific and interspecific levels. In addition, while in other parts of the world, the economic effects of the $C$. fragile invasions have mainly affected tourism and harbor activities, in northern Chile, it will probably impact more importantly the shellfish and seaweed farming industries.

\section{ACKNOWLEDGMENTS}

We are grateful to Drs. Juan Correa, Enrique Martínez, and Sylvain Faugeron, for the materials collected and to Paula Neill for the photo of fresh specimens in Caldera Bay. This study was supported by FONDECYT (Grant $\mathrm{N}^{\circ}$ 1920855 to B.S.).

\section{LITERATURE CITED}

ARDISSONE F (1888) Le alghe della Terre del Fuoco raccolte dal prof Spegazzini. Realle Instituto Lombardo Science e Lettere Rendiconti, ser 2, 21 : 208-215.

BURROWS EM (1991) Seaweeds of the British Isles. Chlorophyta Natural History Museum, London, United Kingdom. 238 pp.

CARLTON JT \& JA SCANLON (1985) Progression and dispersal of an introduced alga: Codium fragile ssp tomentosoides (Chlorophyta) on the Atlantic coast of North America. Botanica Marina 28:155-165.

COLEMAN A (1996) DNA analysis methods for recognizing species invasion: the example of Codium, and generally applicable methods for algae. Hydrobiologia 326/327: 29-34.

DAWSON EY, C ACLETO \& N FOLDVIK (1964) The seaweeds of Peru. Nova Hedwigia 13: 1-111.

GARBARY DJ, H VANDERMEULEN \& K KIM (1997) Codium fragile ssp tomentosoides (Chlorophyta) invades the Gulf of Saint Lawrence, Atlantic Canada. Botanica Marina 40: 537-540.

GARBARY DJ \& CB JESS (2000) Current status of the invasive green alga Codium fragile in eastern Canada. Journal of Phycology (Supplement) 36: 23-24.

GOFF LJ, L LIDDLE, PC SILVA, M VOYTEK \& AW COLEMAN (1992) Tracing species invasion in Codium, a siphonous algae, using molecular tools. American Journal of Botany 79: 1279-1285.

HOWE MA (1911) Phycological studies. V. Some marine algae of lower California, México. Bulletin of the Torrey Botanical Club 38:489-514, plates 27-34.

HOWE MA (1914) The marine algae of Perú. Memoirs of the Torrey Botanical Club 15: 1-185.

HUBBARD CB \& DJ GARBARY (2002) Morphological variation of Codium fragile (Chlorophyta) in eastern Canada. Botanica Marina 45: 476-485.

HYLMÖ DE (1919) Zur Kenntniss der subantarktischen und antarktischen Meeresalgen III Chlorophyceen. In: Nordenskjold $O$ (ed) Wissenschaftliche Ergebnisse der schwedischen Sudpolar-Expedition 1901-1903, Stockholm, Sweden 4: 1-20, plates 33.

MENESES I \& A HOFFMANN (1994) Contribution to the marine algal flora of San Félix Island, Desventuradas Archipelago, Chile. Pacific Science 48: 464-474.

MENESES I \& B SANTELICES (2000) Patterns and breaking points in the distribution of benthic algae along the temperate Pacific coast of South America. Revista Chilena de Historia Natural 73: 615-623.

RAMÍREZ M \& B SANTELICES (1991) Catálogo de las algas marinas bentónicas de la costa temperada del Pacífico de Sudamérica. Monografías Biológicas, Pontificia Universidad Católica de Chile, Santiago, Chile. 437 pp.

SANTELICES B (1980) Phytogeographic characterization of the temperate coast of Pacific South America. Phycologia 19:1-12. 
SANTELICES B \& I MENESES (2000) A reassessment of the phytogeographic characterization of Temperate Pacific South America. Revista Chilena de Historia Natural 73: 605-614.

SETCHELL WA (1937) The Codiums of the Juan Fernández Island. In: Skottsberg C (ed) The natural history of Juan Fernández and Eastern Island 2: 587-600, plates 34-48 Uppsala, Sweden.

SILVA P (1951) The genus Codium in California with observations on the structure of the walls of the utricles. University of California Publications in Botany 25: 79-114.

SILVA P (1955) The dichotomous species of Codium in Britain. Journal of the Marine Biological Association of the United Kingdom 34: 565-577.

SILVA P (1957) Codium in Scandinavian waters. Svensk Botanisk Tidskrift 51: 117-134.

SILVA P (1959) The genus Codium (Chlorophyta) in South Africa. Journal of South African Botany 25:103-165.

SILVA P (1992) Geographic patterns of diversity in benthic marine algae. Pacific Science 46: 429-437.

SILVA P \& HBS WOMERSLEY (1956) The genus Codium (Chlorophyta) in southern Australia. Australian Journal of Botany 4: 261-289.

SVEDELIUS N (1900) Algen aus den Landern der Magellansstrasse und Westpatagonien I. Chlorophyceae. In: Nordensjold $\mathrm{O}$ (ed) Wissenschaftliche Ergebnisse der schwedischen Expedition nach den Magellanslandern (1895-1897) 3: 283-316. Stockholm, Sweden.

TROWBRIDGE CD (1995) Establishment of the green alga Codium fragile ssp. tomentosoides on $\mathrm{New}$
Zealand rocky shores: current distribution and invertebrate grazers. Journal of Ecology 83: 949965.

TROWBRIDGE C (1996) Introduction versus native subspecies of Codium fragile: how distinctive is the invasive subspecies tomentosoides. Marine Biology 126: 193-204

TROWBRIDGE C (1998) Ecology of the green macroalgae Codium fragile (Suringar) Hariot: invasive and non-invasive subspecies. Oceanography and Marine Biology: an Annual Review 36: 1-64.

TROWBRIDGE C (1999) An assessment of the potential spread and options for control of the introduced green macroalga Codium fragile ssp. tomentosoides on Australian shores. Codium in Victoria waters. Centre for Research on Introduced Marine Pests, CSIRO, Marine Research. 43 pp.

TROWBRIDGE CD (2002) Coexistence of introduced and native congeneric algae: Codium fragile and $C$. tomentosum on Irish rocky intertidal shores. Journal of the Marine Biological Association of the United Kingdom 81: 931-937.

TROWBRIDGE CD \& C TODD (1999) The familiar is exotic: II Codium fragile ssp tomentosoides on Scottish rocky intertidal shores. Botanical Journal of Scotland 50: 161-179.

WIEDENMANN J, A BAUMSTARK, TL PILLEN, A MEINESZ \& W VOGEL (2001) DNA fingerprints of Caulerpa taxifolia provide evidence for the introduction of an aquarium strain into the Mediterranean sea and its close relationship to an Australian population. Marine Biology 138: 229-234. 